\title{
INDETERMINATE CONFINEMENT: LETTING THE THERAPY FIT THE HARM*
}

\author{
Alan M. Dershowitz $\dagger$
}

From the beginning of recorded history, lawmakers have attempted to construct theories of proportionality that fit punishment to crime. The Biblical "eye for an eye" reflects at once the importance of proportionality and the difficulty of going beyond simplistic symmetry. The elusive quest for the "fitting" punishment has led to a bizzare array of sanctions down through the ages, ranging from removal of the offending limb ${ }^{1}$ to execution of the offender's son for the killing of another's son. ${ }^{2}$ In recent centuries, since the advent of imprisonment as the dominant response to crime, the debate over proportionality has shifted from modes of punishment to duration of confinement. ${ }^{3}$ The twentieth century, however, has witnessed a general erosion of interest in proportionality between crime and punishment. ${ }^{4}$ The age of therapy deemed itself capable of dispensing with what it viewed as an anachronistic vestige of retributivism. "Criminals are sick," claimed the apostles of the new criminology. "They must be treated, not punished." And treatment, unlike punishment, the argument went, cannot be bounded by considerations of justice. Effectiveness, not fairness, has been the hallmark of this age.

* An early version of this article was presented at the Ninth International Academy of Comparative Law in 1974.

$\dagger$ Professor of Law, Harvard University. B.A. 1959, Brooklyn College; LL.B. 1962, Yale University. Member, District of Columbia and Massachusetts Bars. Law Clerk to Chief Judge Bazelon, 1962-63.

${ }^{2} C f$., e.g., Unesaneh Tokeph, prayer from the Jewish High Holiday Service, in Synagogue Service (H. Adler \& A. Davis eds. 1959).

2 See, e.g., Code of Hammurabi \$§ 116, 209-10 \& 229-30, in J. Smith, The Origin and History of Hebrew Law 197, 211,213 (1931). Proportionality has even been the object of comical derision: see, e.g., Gilbert, The Mikado, in The Mikado \& OTHER OpERAS (1929), act II, at 188-89.

${ }^{3}$ For a case which combines these concerns, see Weems v. United States, 217 U.S. 349 (1910).

Much of the concern over proportionality during recent years has been focused on the capital sanction. See Furman v. Georgia, 408 U.S. 238 (1972). 
But a new era appears to be upon us. The age of therapyof exclusive reliance on the scientific expert-is beginning its decline. The expert, once venerated, is now being challenged in many forums. It is no longer enough to pronounce; he must now justify. The 1960's were a watershed between eras. That decade witnessed a rekindling of interest among courts, legislators, and scholars in concepts of justice. Many factors contributed to the emerging skepticism concerning expertise and the return to a concern for fairness and proportionality. Chief Judge David Bazelon, once an honored statesman of the age of therapy, has emerged as the prophet of this new skepticism. His judicial opinions, perhaps better than any other writings, reflect the transition from the age of therapy to what may someday come to be called the age of informed justice.

This Article will consider one essential element of any approach to informed justice: proportionality between the sanction authorized by the government and the underlying harm or danger to which the sanction is responsive. It will focus on one sanction: confinement. And it will address one issue in the application of that sanction: to what extent should confinement be indeterminate in duration and dependent primarily on considerations of treatability and danger, and to what extent should it be determinate in duration and dependent primarily on considerations of justice and proportionality?

\section{The Indeterminate Sentence Defined}

The indeterminate sentence is not a unitary concept of precise definition. It is a continuum of devices designed to tailor punishment, particularly the duration of confinement, to the rehabilitative needs and special dangers of the particular criminal (or more realistically, the category of criminals).

A sentence is more or less indeterminate to the extent that the amount of time actually to be served is decided not by the judge at the time sentence is imposed, but rather by an administrative board while the sentence is being served. Thus, a judicially imposed sentence of one day to life, the actual duration to be determined by the parole board after service of sentence has commenced, is entirely indeterminate; a judicially imposed sentence of life imprisonment with no possibility of parole (or other discretionary reduction) is entirely determinate. ${ }^{5}$ Be-

${ }^{5}$ It is, of course, true that virtually all sentences can be shortened by executive clemency, pardon, and the like. In that sense, all sentences may be regarded as indeter- 
tween these terminal points of the continuum lie a wide range of more or less indeterminate sentences. A judicially imposed sentence of not less than five nor more than ten years is partially indeterminate: although its maximum and minimum are fixed at the time of sentencing, the actual time to be served within those limits will be decided subsequently by some administrative authority. Another form of indeterminate sentence is the judicially imposed term of imprisonment for what appears to be a fixed period, say ten years, but subject to the normal rules of parole, under which an administrative board has discretion to authorize release after a statutorily prescribed percentage of "the sentence" has been served. Thus, all sentences subject to parole (the vast majority of prison sentences imposed in the United States today) are indeterminate to some degree.

The concept of indeterminancy is not applicable exclusively to punitive criminal sentences. Orders of involuntary confinement that do not bear punitive labels-such as commitment of the insane, addicts, juvenile delinquents, defective delinquents, and sexual psychopaths-are typically indeterminate; indeed, they tend to be even more indeterminate than criminal sentences. Commitments of the mentally ill, sexual psychopaths, and defective delinquents are wholly indeterminate as a general rule. "Non-punitive" confinements of juveniles and addicts usually have upper time limits, but give administrative boards discretion to determine the actual duration of the confinement within these limits.

Hence, the indeterminate sentence, viewed in proper perspective as a continuum, is not merely a "special" sentencing procedure; in its many variations, ${ }^{6}$ it is the dominant me-

minate. But executive intervention theoretically is reserved for special situations, and therefore will not be considered in this Article. Nor will the Article consider mandatory "good time" provisions, which autømatically reduce a given sentence by a certain amount if the prisoner complies with prison rules. While large elements of discretion certainly enter into "good time" decisions, such decisions are not (at least theoretically) part of the indeterminate sentence structure. They did, however, play an important role in the early history of what ultimately evolved into the indeterminate sentence. See notes 26-27 infra \& accompanying text.

6 The various forms of indeterminate sentence are practically unlimited. For example, in 1925, Edward Lindsey catalogued the following 13 variations that he said existed by 1922:

1. The sentence indefinite in form but the maximum period of detention limited by the Act to the maximum prescribed by law for the offense of which the prisoner was convicted. This is the form adopted in the case of the reformatories generally, wherever located, and is patterned after the Elmira Act.

2. The sentence indefinite in form but with both maximum and minimum period of detention limited by the Act to the maximum and minimum 
chanism of involuntary confinement currently employed in the United States. ${ }^{7}$ It is extremely rare for a convicted criminal or a committed "patient" to know, at the time judgment is formally imposed by the court, precisely how long he actually will be retained in confinement.

In practical terms, of course, most criminal sentences fall closer to the determinate than the indeterminate pole of the

prescribed by law for the offense of which convicted. This form was adopted in Ohio, Michigan, Minnesota and Illinois.

3. A maximum and minimum period to be fixed by the court in the sentence but with the provision in the Act that the maximum shall not exceed the maximum prescribed by law for the offense. New York.

4. The court to fix the maximum and minimum period of detention in the sentence but with the provision in the Act that the maximum shall not exceed the maximum prescribed by law for the offense and the minimum shall not be less than two and one-half years. Massachusetts.

5. The court to name the maximum and minimum period of detention in the sentence, which shall be the maximum and minimum prescribed by law for the offense. The Indiana Act.

6. A maximum and minimum term to be fixed by the court in the sentence which must be within the maximum and minimum terms prescribed by law for the offense of which the prisoner was convicted. This form first appeared in the Kansas Act and was adopted also by New Hampshire, New Mexico, Kentucky, Wyoming, Washington and by the New York Act of 1909.

7. A maximum and minimum term to be fixed by the court in the sentence; the maximum shall be the maximum prescribed by law for the offense and the minimum shall not be less than the minimum prescribed by law for the offense and not more than one-half the maximum. Idaho.

8. A maximum term to be fixed by the court in the sentence which shall not exceed the maximum prescribed by statute for the offense. This form was adopted in Minnesota and Oregon.

9. The court to fix in the sentence a minimum term which shall be the minimum prescribed by statute for the offense and a maximum term which shall be the time fixed by the jury in its verdict. Adopted in Texas.

10. The court to fix in the sentence a maximum term which shall be the maximum prescribed by statute for the offense and a minimum which shall not be less than one year nor more than one-half the maximum. New Jersey.

11. The court to fix in the sentence a maximum term which shall not exceed the maximum prescribed by statute for the offense and a minimum term which shall be the minimum prescribed by statute for the offense. Maine.

12. The court to fix in the sentence a minimum term within the limits prescribed by statute for the offense, but no prisoner to be detained beyond the maximum prescribed by statute for the offense. Ohio.

13. The jury to fix a maximum and minimum in its verdict within the maximum and minimum prescribed by statute for the offense. Georgia.

In 1922, 44 states, the territory of Hawaii, and the federal government had parole systems; 37 of these had some form of indeterminate sentencing; only 4 states were without either. Lindsey, Historical Sketch of the Indeterminate Sentence and Parole System, $16 \mathrm{~J}$. CRIM. L.C. \& P.S. 9, 39, 58, 69 (1925).

: To be sure, a considerable percentage of incarcerated prisoners are not serving sentences at all, but are awaiting trial. Pretrial confinement, however, will not be considered here, even though it raises some problems relevant to indeterminate sentencing. 
continuum, and most prisoners, with the help of their lawyers, can make a fairly accurate calculation of the amount of time that they will serve if they behave well in prison. ${ }^{8}$ As with all complex human institutions, a certain predictability eventually sets in and a special language develops. (Thus, a convicted federal first offender sentenced to three years for extortion can generally expect to serve approximately nineteen months in prison. ${ }^{9}$ ) Predictability will depend on a number of factors, including the range of the available sentence, the seriousness (particularly the violence) of the underlying offense, the prior record of the offender, the publicity attached to the particular crime or criminal, and the policies of the releasing agency.

\section{A. Some Inherent Effects of Indeterminate Sentences}

The differences between indeterminate and determinate sentencing are generally a function of the fact that to the extent a sentence is fixed, a judge imposes it before the defendant has begun to serve it, whereas to the extent a sentence is indeterminate, an administrative agency imposes it while it is being served. These differences produce several important effects, three of which seem most significant.

1. To the extent that a judge has the power to determine the sentence at trial, he is more likely to consider the defendant's conduct at the trial and prior thereto. Thus, judicial sentencing focuses on such factors as whether the defendant pleaded guilty or not guilty, whether he cooperated with the prosecutor, and whether he committed perjury at the trial. ${ }^{10}$

${ }^{8}$ Struggle for Justice: A Report on Crime and Punishment in America, Prepared for the American Friends Service Committee 96 (1971).

${ }^{9}$ United States Bureau of Prisons, Dep't of Justice, Federal Bureau of Prisons Statistical Report Fiscal Years 1971 and 1972, at 152-53. However, only 27 convicted extortionists were released in 1971-72.

Were it not for some predictability, plea bargaining would be more difficult than it currently is. But see J. Mitrord, Kind \& Usual Punishment 92-93 (1973).

${ }^{10}$ Much attention currently is being focused on the general question of sentencing discretion. This question transcends that of the indeterminate sentence; it concerns also the range of sentences available to trial judges. The problem of sentencing discretion would still remain if judges were required to fix a wholly determinate sentence, so long as they were empowered to select that sentence from a wide range of legislatively authorized alternatives. To state an extreme case: consider, for example, a statute that permitted the sentencing judge to select any term of years between one and fifty as the appropriate sentence for armed robbery but required him to fix the sentence with precision at the time of imposition (e.g., 18 years, without the possibility of parole). Under such a sentencing scheme, no discretion would be vested in an administrative agency, but extremely broad discretion would be vested in the judge. One of the avowed pur- 
To the extent that an administrative agency has the power to determine the sentence while the defendant is serving it, it is more likely to consider the defendant's conduct in prison, focusing on such factors as the prisoner's disciplinary record and his general cooperativeness as a prisoner. The point in the process at which the sentence is actually determined is probably not the only reason for this difference: judges, being lawyers who identify more with the prosecution function in the criminal process, naturally use their power more in the service of that aspect of the process (by rewarding pleas of guilty and cooperation with the prosecutor), whereas members of the parole board generally identify more closely with the corrections functions of the process, and use their power more in the service of that aspect of the process (by rewarding prison cooperation and good behavior).

2. To the extent a sentence is determined later rather than earlier in the process, the sentencing authority naturally will look more to the future than to the past. The later in the process the sentencing takes place, the closer it is in time to release. There is more information about release plans, job prospects, current mental conditions, and prisoner attitudes. The crime itself is further in the past, and community hostility-except for notorious crimes-is less likely to be an overriding consideration. Put in practical terms, the judge sentencing early in the process is more likely to ask himself how the community will react if the sentence is disproportionate to the past crime, whereas the agency sentencing later in the process is likely to ask itself how the community would react if the released prisoner were to recidivate. ${ }^{11}$ Thus, predictive considerations, though they undoubtedly enter into all sentencing decisions no matter by whom or when they are made, may play a greater role in indeterminate sentencing than in fixed sentencing.

3. To the extent that a sentence is imposed by a judge at the close of trial, it is far more amenable to appellate challenge and review than if it is determined later by a board. Defendants are generally represented by counsel at the time of judicial sen-

poses of the relatively indeterminate sentence is to counteract the enormous disparities in sentences imposed by different judges for similar offenses. The theory is that a professional agency acting collectively will produce less disparity than individual judges.

11 These considerations merge, of course, when the sentencing judge is deciding whether to impose a prison sentence at all. 
tencing, but not while they are serving an indeterminate sentence. ${ }^{12}$ A related reason is that the appeal from conviction provides a convenient vehicle to which to attach a sentencing challenge; it is far more difficult to bring an action challenging an ongoing sentence whose duration has not yet been determined. ${ }^{13}$

\section{B. The Effect of Indeterminate Sentencing on the Duration of Imprisonment}

Disproportionately high penalties are not inherent in indeterminate sentencing, but the introduction of this method of sentencing has coincided with a sharp increase in the confinement statutorily authorized for particular crimes and in the judicial maxima actually imposed. ${ }^{14}$ Moreover, there is evidence, albeit inconclusive, that prisoners incarcerated under indeterminate sentencing laws serve longer terms of imprisonment than prisoners convicted of comparable crimes in jurisdictions using relatively fixed sentences. In 1937, one commentator summarized the evidence as follows:

While parole was originally conceived of as a means of shortening the period of incarceration of deserving inmates who could be trusted with conditional freedom, it has become, in actual practice, a mechanism by which something is added on to prison sentences. The universal conclusion of studies of time served in prison under indeterminate sentence laws and time served under the old definite sentence laws in the same jurisdictions has been that the indeterminate sentences have very materially increased the time served within the walls. ${ }^{15}$

In 1956, another scholar reported a similar conclusion:

It is clear that no matter what other factors govern

${ }^{12} \mathrm{~A}$ case can be made for the right to counsel at all times before the sentence is actually decided upon by the board, but that is not the current law.

${ }^{13}$ Recent decisions may, however, make it easier to challenge ongoing sentences; see In re Lynch, 8 Cal. 3d 410, 503 P.2d 921, 105 Cal. Rptr. 217 (1972).

${ }^{14}$ Rubin, The Indeterminate Sentence-Success or Failure?, NPPA Focus, March 1949, at 47; Rubin, Long Prison Terms and the Form of Sentence, 2 NPPA J. 337, 344-47 (1956). See also Tappan, Sentencing Under the Model Penal Code, 23 Law \& Contemp. Prob. 528, 531 (1958): "Another [consequence of the indeterminate sentence and parole] has been the establishment in certain jurisdictions of what seems unnecessarily high permissible terms...."

15 VanVechten, The Parole Violation Rate, 27 J. CRIM. L.C. \& P.S. 638 (1937). 
sentence length, the inevitable result of the indeterminate sentence is that sentences of over five years will strongly predominate; and in a definite sentence state sentences of under five years will strongly predominate. ${ }^{16}$

At least one distinguished observer disputes the existence of a causal effect by attributing this difference to the impact of other factors, including the higher volume of crime in many of the states with indeterminate sentence laws. ${ }^{17}$

In sum, indeterminate sentences and longer terms often are found together, and this is probably not entirely coincidental, although no strictly causal relationship has been shown.

\section{The Origins of the Indeterminate Sentence}

Since the indeterminate sentence relates primarily to the duration of confinement, it is not surprising to learn that it first received systematic attention with the development of confinement as the dominant response to crime. Indeterminacy has little meaning in the context of capital punishment, whipping, fines, or other penalties whose imposition is commenced and

${ }^{16}$ Rubin, Long Prison Terms and the Form of Sentence, 2 NPPA J. 337, 347 (1956).

${ }_{13}$ Presumably, higher sentences in a high crime jurisdiction reflect an effort to deter crime in response to the high rate. Another factor cited is that 13 of the 18 "definite sentence" jurisdictions are southern states; this region traditionally has employed a policy of low sentences, except in special cases. Tappan, supra note 14 , at 532,535 .

These factors, however, cannot explain intrastate sentence duration disparities, such as existed in Connecticut until 1968. A statute there permitted the possibility of certain women offenders on indeterminate terms being subject to longer maximum sentences than could be given to men serving relatively determinate terms for the identical offenses. Three 1968 cases invalidated the scheme. United States ex rel. Sumrell v. York, 288 F. Supp. 955 (D. Conn. 1968); United States ex rel. Robinson v. York, 281 F. Supp. 8 (D. Conn. 1968); Liberti v. York, 28 Conn. Supp. 9, 246 A.2d 106 (Super. C.t. 1968).

Laws in Pennsylvania and New Jersey until recently required many women to receive indeterminate sentences with the maximum set at the maximum allowed for the crime, while men could receive shorter minimum-maximum terms at the discretion of the judge. The laws were invalidated on equal protection grounds. Commonwealth $v$. Daniel, 430 Pa. 642, 243 A.2d 400 (1968); State v. Chambers, 63 N.J. 287, 307 A.2d 78 (1973). See also text accompanying notes 118-26 infra. The sentencing schemes did not necessarily mean that women served longer sentences than men, although a study has indicated that mandatory indeterminate terms usually do result in female offenders serving more time than their male counterparts, see Comment, Sex and Sentencing, 26 Sw. L.J. 890 (1972). At the very least the Pennsylvania and New Jersey statutes made women subject for reincarceration for parole violations for a longer period than most men, see $430 \mathrm{~Pa}$. at 647 n.*, 243 A.2d at 402-03 n.6. The Supreme Court of New Jersey characterized the rationale of the statutes as follows: "that females are better subjects for rehabilitation, thereby justifying a potentially longer period of detention for that purpose ...." 63 N.J. at $296,307 \mathrm{~A} .2 \mathrm{~d}$ at 82 . 
completed within a brief period (though torture was sometimes ordered to continue until the victim performed a specific act, such as confessing his guilt). Indeterminacy does have meaning in the context of banishment (for example, "You are sentenced to be banished until you reform") and there is some evidence that a form of indeterminacy was used by the English in the administration of their "transportation" system. ${ }^{18}$

Although the origins of the indeterminate sentence are generally traced to the last third of the nineteenth century, it seems likely that some degree of indeterminacy, formal or informal, existed much earlier than that for at least certain kinds of sentences. ${ }^{19}$ The "preventive justice" sentences meted out at common law by justices of the peace against "those persons whom there is probable ground to suspect of future misbehavior"20 and who could not obtain sufficient sureties were often for indeterminate periods: the confined peace-threatener could be discharged "by the demise of the king,"21 by "order of the court . . . if they see sufficient cause," 22 or by the failure of the moving party to request its continuance. ${ }^{23}$

The imprisonment of madmen who committed, but who could not be convicted of, criminal acts has probably always been for an indeterminate period, as a thirteenth century English case illustrates. Richard of Cheddestan, who killed his wife while "in the grip of a frenzied sickness," was "wretchedly detained" in prison. After six years, the king made inquiry "whether the aforesaid Richard is restored to his former soundness of mind, or whether it would be dangerous if he were released." A jury was convened and it decided that al-

${ }^{18}$ A convict who had been transported to Australia could, "by good conduct," rise through "two or three grades" and eventually be freed and pardoned. Lindsey, supra note 6 , at 11 .

${ }^{19}$ Even the Old Testament prescribes a sort of indeterminate sentence for the person who accidentally kills another: "the congregation shall restore him to the city of his refuge, . . . and he shall abide in it unto the death of the high priest." Numbers 35:25. While the duration of that confinement was not, of course, known at the time sentence was imposed, it was fixed, in the sense that it terminated upon the occurrence of an event external to the particular needs and dangers of the person confined; indeed, all confined persons were freed on the very same day, regardless of the duration of their confinement.

204 W. Blackstone, Commentaries *251.

${ }^{21} \mathrm{Id}$. *254. There seems to have been little increase in sophistication in this regard between the Biblical age- when release was triggered by the death of the high priestand the Blackstonian age-when it was triggered by the death of the king.

22 Id.

${ }^{23}$ Id. See also M. Dalton, The Countrey Justice 3-5 (1677). 
though Richard was now "well enough," it "cannot safely be said that he is restored to soundness of mind that there would not be a danger in setting him free, especially when the heat of summer is increasing, lest worse befall." "24 (If this ruling sounds strangely similar to the decision of a modern American parole board, it simply demonstrates that human nature, fears, and attitudes have not changed radically over the centuries.)

The confinement of juveniles, though limited by age requirements, was generally indeterminate within fixed limits. As Beaumont and Tocqueville reported about American "houses of refuge" in 1833:

The magistrates who send the children to the refuge, never determine what length of time the delinquent must remain there. ... The office of judging whether a child is fit to leave the refuge [before his twentieth birthday], is left to the managers of the establishment, who ... . designate those to whom liberty may be restored without danger. ${ }^{25}$

It is, of course, not surprising that these special and "noncriminal" forms of confinement would have been of indeterminate duration, since they were designed primarily to achieve prevention and rehabilitation rather than punishment. It is likely, however, that there was some indeterminacy even in conventional criminal sentences of imprisonment from the earliest times. Despite the reputed inflexibility and formality of the law governing the imposition of criminal sentences prior to the last third of the nineteenth century, it is difficult to believe that there were no informal mechanisms available by which to effect early releases in especially compelling cases. The king, or the executive authority in the United States, did exercise a right to pardon, which sometimes was used to reduce prison sentences after a portion was served. Certainly by the beginning of the nineteenth century, and possibly much earlier, a practice developed of commuting certain sentences as a reward for good behavior. ${ }^{26}$ In 1817 , a New York statute was enacted empowering the prison inspectors to reduce fixed sentences by up

${ }^{24}$ Richard of Cheddestan's Case, transl. in 1 N. WALKER, CRIME AND INSANITY IN England 20, 23 (1968).

${ }^{25}$ G. Beaumont \& A. Tocqueville, On the Penitentiary System in the United States and its Application in France 139 (H. Lantz ed. 1964).

${ }^{26}$ Lindsey, supra note 8 , at 10. 
to one-fourth upon a showing that the prisoner had behaved well and had set aside a certain amount of his prison earnings for use upon release. Other statutes authorizing the reduction of fixed sentences were enacted in other states over the next decades. $^{27}$ Most of these seemed to be designed primarily to improve in-prison discipline, rather than to tailor the duration of the confinement to the dangerousness and rehabilitation of the offender (although these goals were probably seen as somewhat complementary).

The idea of a prison sentence without fixed duration, designed to keep the prisoner confined until he was no longer dangerous, began to receive widespread professional support by the middle of the nineteenth century. In 1832, Archbishop Whately of Dublin proposed that criminals "should not be turned loose upon society again until they give some indication that they are prepared to live without a repetition of their offenses." ${ }^{28}$ This, of course, is only one side of the indeterminacy coin: Whately did not propose that convicted prisoners be released as soon as they were prepared to live without recidivating. By 1846, however, a prominent French lawyer proposed that prisoners be allowed "provisional liberty" as soon as their "moral regeneration is sufficiently guaranteed," provided, however, that "a sufficient period of expiation" has passed and that the law authorized their return to prison "on the least well founded complaint."29

The first systematic theoretical justification for the indeterminate sentence appeared in the writings of Cesare Lombroso, an Italian anthropologist, who sought to discover the causes of crime by examining the characteristics of Italian prisoners. In 1876 he published his encyclopedic study, L'Uomo Delinquent (Criminal Man), in which he set forth his controversial theory that most crime is caused-or at least manifested -by discernible physical characteristics of the criminal. ${ }^{30} \mathrm{He}$

${ }^{27} I d$.

${ }^{28} I d .14$.

${ }^{29}$ Id. $14-15$.

${ }^{30}$ G. Lombroso Ferrero, Criminal Man, According to the Classification of Cesare Lombroso (1911) [hereinafter cited as Criminal MaN].

The flavor of Lombroso's early work can be gleaned from his own description of the "revelation" that he experienced upon "laying open the skull" of an infamous criminal who had died:

I found on the occipital part, exactly on the spot where a spine is found in the normal skull, a distinct depression which I named median occipital fossa, because 
presented data on approximately seven thousand different criminals, minutely describing their physical characteristics, both innate and acquired.

In general, many criminals have outstanding ears, abundant hair, a sparse beard, enormous frontal sinuses and jaws, a square and projecting chin, broad cheekbones, frequent gestures, in fact, a type resembling the Mongolian and sometimes the Negro. ${ }^{31}$

The special taste of criminals for a painful operation so long and so full of danger as tatooing, the large number of wounds their bodies present, have led me to suspect in them a physical insensibility greater than amongst most men, an insensibility like that which is encountered in some insane persons and especially in violent lunatics. ${ }^{32}$

Lombroso's "scientific" approach naturally led him to advocate preventive measures: "It is no longer enough to repress crime: we must try to prevent it." 33 He proposed two approaches to the prevention of crime: the first focused broadly on the general causes of certain kinds of crime; $;^{34}$ the second

of its situation precisely in the middle of the occiput as in inferior animals, especially rodents. This depression, as in the case of animals, was correlated with the hypertrophy of the vermis, known in birds as the middle cerebellum.

This was not merely an idea, but a revelation. At the sight of that skull, I seemed to see all of a sudden, lighted up as a vast plain under a flaming sky, the problem of the nature of the criminal-an atavistic being who reproduces in his person the ferocious instincts of primitive humanity and the inferior animals. Thus were explained anatomically the enormous jaws, high cheekbones, prominent superciliary arches, solitary lines in the palms, extreme size of the orbits, handle-shaped or sessile ears found in criminals, savages, and apes, insensibility to pain, extremely acute sight, tattooing, excessive idleness, love of orgies, and the irresistible craving for evil for its own sake, the desire not only to extinguish life in the victim, but to mutilate the corpse, tear its flesh, and drink its blood.

Lombroso, Introduction to id. at xiv, xv. This quotation reveals both the virtues and limitations of Lombroso's method of inquiry: he was thoroughly inductive, seeking his information exclusively from hard data; but he was willing to make grand generalizations from a small number of cases.

${ }^{31}$ M. Parmelee, Introduction to C. Lombroso, Crime, Its Causes and Remedies at xviii (1912), quoting in translation from I C. Lombroso, HoMme CrIminel 222 (French ed. 1895).

${ }^{32}$ Id. xix-xx, quoting in translation from I HoMme Criminel 310.

${ }^{33}$ C. Lombroso, Crime, Irs Causes and Remedies, $\S 130$, at 245 (1912).

${ }^{34} \mathrm{His}$ proposals dealing with the general causes of crime seem eminently sensible, even after three-quarters of a century. For example, he argued that "the distribution of wood to the poor stops thefts in the forests better than a crowd of gendarmes," and that " $[\mathrm{b}] \mathrm{road}$, electric-lighted streets are better than policemen to prevent theft and rape. 
focused more narrowly on the individual criminal or class of criminals. He argued that:

[T] he penalty should be indeterminate, and should be subdivided according to the principle of Cicero: 'A natura hominis discenda est natura juris.' [The nature of law is to be learned from the nature of man.] We must make a difference according to whether we have under our eyes a born criminal, an occasional criminal, or a criminal by passion. ${ }^{35}$

The born criminals and the "criminaloids who have become habitual criminals"36 should be "set at liberty again only after extraordinary proof of reformation." 37

[S]ociety ought not to wait while he perfects himself in crime by a new sojourn in prison, but should keep him shut up until assured of his reformation, or, better, of his powerlessness to do harm. We should, for this end, establish special penal institutions, to which a jury composed of directors, physicians, and judges shall consign all the individuals who, having from infancy shown an inclination toward crime, have relapsed several times, especially if they present those physical and psychical characteristics which we have seen to be marks of the born criminal. ${ }^{38}$

Some criminals, Lombroso acknowledged, "ought never to be liberated."39

Lombroso analogized the preventive imprisonment of the irresponsible born criminal to the confinement of the insane, finding the principal justification for the latter in society's right to defend itself, ${ }^{40}$ and stating:

Now, just as men came to recognize a century ago, contrary to the beliefs of the Middle Ages, that insanity did not depend upon free will, we must now recognize that neither does crime itself depend upon it. Crime and in-

\footnotetext{
... In the political sphere, a really liberal government, like that of England, prevents anarchistic insurrections and acts of revenge, just as entire liberty of the press prevents corruption of the government and insurrections of the governed." Id. 246.

${ }^{35} \mathrm{Id}$. $\$ 210$, at 386 .

${ }^{36} \mathrm{Id}$. $\S 235$, at 419 .

${ }^{37}$ Id. § 237, at 425 .

${ }^{38}$ Id. 424.

${ }^{39}$ Id. § 236, at 423.

${ }^{40} \mathrm{Id}$. 421-22.
} 
sanity are both misfortunes; let us treat them, then without rancor, but defend ourselves from their blows. ${ }^{41}$

Lombroso criticized the classical school of Kant and Hegel as both vengeful and ineffective:

And with all this the State does not think of the morrow. It shuts the prisoner up, and when he has served the term of his sentence it sets him at liberty again, thus increasing the danger of society, for the criminal always becomes more depraved in the promiscuity of the prison, and goes out more irritated and better armed against society. With this theory it is not possible to justify the increase of the penalty in the case of recidivism nor the adoption of preventive measures. ${ }^{42}$

While Lombroso's basic thesis of the physical causes of criminality has had little impact in the United States, his ideas as to reform of the criminal justice system found some implementation here. Lombroso himself commented:

One nation, however-America-gave a warm and sympathetic reception to the ideas of the Modern School which they speedily put into practice, with the brilliant results shown by the Reformatory at Elmira, the Probation System, Juvenile Courts, and the George Junior Republic. They also initiated the practice, now in general use, of anthropological co-operation in every criminal trial of importance. ${ }^{43}$

The conclusions of Lombroso were soon criticized, especially by those who feared the hasty release of criminals regarded by the experts as cured. But the most cogent and farsighted criticisms of Lombroso's approach to sentencing were made by Ramond Salielles, a French criminologist, in 1908. While he agreed that prevention of crime should be the primary

${ }^{41}$ Id. $42 \mathrm{I}$. Cf. Cross v. Harris, 418 F.2d 1095, 1110 (D.C. Cir. 1969) (Burger, J., concurring and dissenting in part); text accompanying note 157 supra.

${ }^{42}$ C. Lombroso, supra note $33, \S 209$, at 383 .

${ }^{43}$ Lombroso, Introduction to G. Lombroso FerRero, supra note 30 , at xix-xx. This of course was a considerable overstatement of the actual situation in the United States.

Lombroso recommended the employment of anthropology not only to help determine the length of confinement, but also to help solve crimes. He spoke of persons who were "anthropologically suspected of the crime," C. LomBroso, supra note $33, \S 243$, at 436 , and claimed that "[c]riminal anthropology can ... help us to discover the real culprits ... [and] also save ... innocent persons accused or convicted." Id. § 244, at 437. 
goal of the criminal justice system, he was wary of Lombroso's devaluation of liberty in favor of security:

Preventive measures that shall place the criminal under the power of the law before the commission of the crime involve the detection and treatment of suspects. Yet, however solicitous one may be for the social safety, it is far better to run the risk of having thefts or other crimes committed, than to condemn any and every man on the basis of his features-merely because nature has given him a jaw, a lip, or a skull that corresponds to one of Lombroso's criminal types. In the life of society, as elsewhere, there are always risks to be run; one must learn how to accept them and to find wherein lies the least social risk. If through fear of crime men are deprived of liberty, where is the advantage? ... [L]et us beware of introducing a system based upon suspicion, which, in its endeavors to provide complete security, constantly exposes men to the serious danger of an accusation upon appearance alone. ${ }^{44}$

Thus Salielles and his followers, who named themselves the "penological school," distinguished themselves from the "positivist" school by rejecting the preventive criminology which advocated preventive confinement of the criminal before he committed the crime. ${ }^{45}$ But they did accept, and attempted to build on, the preventive goal of the Italian positivist school.

Salielles agreed with Lombroso that the criminal law should no longer be exclusively concerned with expiating the past but should focus instead on the cure and prevention of crimes. However, he insisted that no criminal punishment should ever be imposed without conviction for a past offense:

[F]or an action to be punishable and justify prosecution its formal features must correspond to one of the legal prescriptions. It is the crime as defined that alone permits prosecution, but it is the criminal act, or rather the agent, the author of the crime, that should be the object of punishment. The objective aspect of crime determines the prosecution, and the subjective aspect determines the punishment. Such is the division to be

44 R. Salielles, The Individualization of Punishment $\S 42$, at 123 (transl. 2d French ed. 1911).

${ }^{45}$ Id. $\S \S 41-42$. 
made between the two considerations. A place remains and should always remain for the objective side of crime and punishment. ${ }^{46}$

Once this condition was satisfied, however, and the defendant was convicted of a crime, preventive and rehabilitative considerations should be paramount in determining the duration of the confinement:

It is . . . quite useless to set the punishment according to the crime. The duration of the punishment must intimidate and stand as the penalty of the crime, and since it is the nature of the criminal that determines how the punishment is felt and regarded, and since this also conditions the psychological effect, it is according to the moral nature of the criminal that the nature of the discipline and the reformatory status of the punishment should be graded. ${ }^{47}$

While Salielles was wary of a society in which individuals are initially incarcerated because of a criminal "propensity," he felt that once an individual had committed a crime, notions of personal liberty became subservient to the protection of society from crime. This method of balancing the values of liberty and security received widespread acceptance in the United States. ${ }^{48}$

${ }^{46} I d$. $\$ 62$, at 186 .

${ }^{47} I d$. $\S 88$, at 275 . Salielles also faulted the Lombroso School for not being "tough" enough on those who were not criminal "types" under Lombroso's classification, but who nevertheless committed crimes. Id. $\S 42$, at 123-24. Though Salielles emphasized his normative dispute with Lombroso, he also called attention to the paucity of predictive information. Id. $\S 43$, at 127 . Salielles himself believed that "pathological abnormalities are found among the majority of criminals," but he doubted whether such signs were "characteristic" and "necessarily indicative of criminality." Id. § 44, at 129-30. Moreover, if Lombroso were correct and "if criminality is a chronic pathological expression due to temperament or to an hereditary taint, it is a natural defect; and there is no hope of cure." Id. 128-29.

${ }^{48}$ Salielles was a proponent of what he called "individualization of punishment," a concept that received widespread acceptance-at least in theory-in the United States. There are. of course, a number of decisional points at which "individualization" could be implemented: (1) the legislature could define crimes and/or set penalties by reference to a large number of individualized factors (e.g., a father with no previous criminal record who steals food without hurting anyone for purposes of feeding his hungry family shall be punished by X penalty); (2) the judge (or jury) could be authorized to take certain individualized factors into consideration in setting the penalties for crimes defined in general terms; (3) an administrator or "expert"-such as the prison warden-could determine the duration of confinement based on individualized factors. Salielles rejected the first alternative-which he called "legal individualization"-out of hand: "In reality there is no individualization by law. The law can distinguish classes 
Among the earliest proponents of the indeterminate sentence in the United States was Zebulon Brockway, the long time superintendent of the Elmira Reformatory in New York. In a widely circulated address given before the National Prison Conference in 1870, Brockway suggested preventive measures that foreshadowed many of the techniques generally adopted in the early part of the twentieth century.

According to Brockway, the preventive measure which carried the best hope of "protection against crime" was the "indeterminate reformatory" and the "indeterminate sentence." Rejecting vengeance as unjust and deterrence as a failure, Brockway proposed the following plan for preventive confinement:

[A]ll persons in a state, who are convicted of crimes or offenses before a competent court, shall be deemed wards of the state and shall be committed to the custody of the board of guardians, until, in their judgment, they may be returned to society with ordinary safety and in accord with their own highest welfare. ${ }^{49}$

of cases; it cannot recognize individuals." Id. $\S 72$, at 220 . Salielles argued that there was an important role to be played by judicial individualization, but the role of the judge was limited as well:

It is not the judge who can determine the time of discharge from the penitentiary, but the penitentiary administration itself. The judge signs the warrant and makes the choice of punishment; he determines the institution to which the individual is to be sent; but he does not endorse the discharge.

Id. $\S 93$, at 297. The proper focus of individualization, according to Salielles, was the prison administrator:

The law must grant to the administration sufficient initiative and flexibility in the adjustment of the discipline, so that it may, in turn, adjust the application of the punishment to the educational and moral requirements; and that is what is meant by administrative individualization.

Id. 296. The implication of administrative individualization did not escape Salielles; he realized that under such a system indeterminate confinement was possible, even for persons who had committed relatively minor offenses. Id. 296-97. Salielles acknowledged that the truly indeterminate sentence posed considerable problems and raised dangers of abuse. He recognized as well that indeterminateness is a matter of degree. Id. $\S 95$, at 303-04. Bowing to the realities of political acceptability, Salielles recommended the adoption of a "modified form" of indeterminate sentence under which a general maximum sentence would be established for different crimes, and it would be within the discretion of the prison administrator to determine the time of release, within the limits established by law:

Salielles was quick to point out that in order for such a system to work the permissible maximum must "necessarily" exceed "the normal length of punishment," so that the prisoner "retains an interest in effecting his reform." Id. 304.

4" Z. Brockway, Fifty Years of Prison Service 401 (1912). 
Eschewing "sickly sentimentalism" and "popular philanthrop[y]," Brockway characterized his proposal as hard-nosed realism, designed to "guarantee" the "safety" of society "from further depredations" of convicted criminals. ${ }^{50}$

This approach was stated in the extreme in an influential article in the Yale Law Journal ${ }^{51}$ at the turn of the century. Its author, Charlton T. Lewis, reflected the evolving view of the indeterminate sentence in the United States when he stated that it was the only "right method of dealing with crime" and that its governing principle should be that "no man be imprisoned unless it is clear that his freedom is dangerous to others, and that when once imprisoned, no man be freed until the danger has ceased."52 Considerations of deterrence, retribution, and justice were ignored; and rehabilitation-which he called reconciliation-was only one means of reducing the criminal's dangerousness. He advocated that the crime itself have "no bearing upon the questions"53 since confinement is not "punishment for this offense." 54 With an arrogance unbecoming their lack of evidence, the earliest proponents of indeterminate sentencing were determined to ignore the age-old notion of "natural justice"-that the punishment should fit the crime.

The first explicit indeterminate sentence law for crimes in the United States was enacted at the behest of Zebulon Brockway in the state of Michigan in 1869. It was of extremely limited application, reserved solely for "common prostitutes" and providing for a three-year sentence which could be terminated at any time at the discretion of the inspectors of the Detroit House of Correction. ${ }^{55}$ (It appears that the maximum punishment for prostitution was far less than three years.) Eight years later, Brockway secured the enactment of the first indeterminate sentence law of more widespread penal application. His original proposal was for an indeterminate sentence law "without limitation," but "neither public sentiment in general nor the views of the legislators would accept this." ${ }^{\text {"6 }}$ Instead, New York

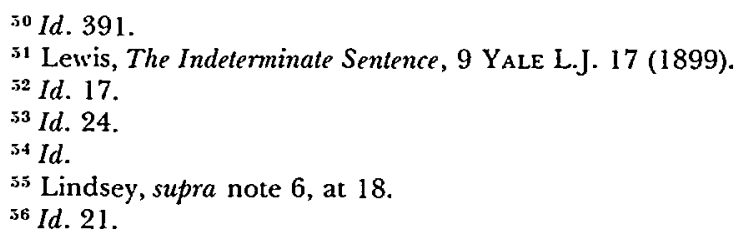


enacted a modified provision which was typical of the statutes enacted in most states in the year following. The New York law limited the term of the sentence to "the maximum term provided by law for the crime for which the prisoner was convicted and sentenced," but left the determination of the exact amount of time to be served to the managers of the reformatory. ${ }^{57} \mathrm{By}$ 1922, thirty-seven states had similar forms of indeterminate sentencing and seven others had parole systems which were functionally similar to the indeterminate sentence. ${ }^{58}$ Since that time there have been few significant changes in the sentencing laws.

\section{The Early Judicial History of Challenges TO INDETERMINATE SENTENCING}

In light of the increased duration of confinement apparently associated with indeterminate sentencing, ${ }^{59}$ it is not surprising that numerous prisoners have challenged their indeterminate sentences in the courts. Most of the early challenges were rejected, though a few succeeded on narrow grounds. For the most part, the courts, citing the arguments of the "reformers," whole-heartedly approved of indeterminate sentencing and found such sentences to comport with state and federal constitutional provisions. Typical of this attitude was the preface to the Supreme Court of Ohio's rejection of an early challenge:

[This act] marks a new experiment in the management and discipline of prisoners. ... It is evidently prompted by a desire to reform as well as to punish; to make better those under sentence, as well as to protect society. ... The paramount object is the welfare of society; hence the sentence to imprisonment of those convicted and hence also the effort to educate and reform the

\footnotetext{
"IId. The relevant section provided as follows:

Every sentence to the reformatory of a person hereafter convicted of a felony or other crime shall be a general sentence to imprisonment in the New York State reformatory at Elmira and the courts of this state imposing such sentence shall not fix or limit the duration thereof. The term of such imprisonment of any person so convicted and sentenced shall be terminated by the managers of the reformatory, as authorized by this act; but such imprisonment shall not exceed the maximum term provided by law for the crime for which the prisoner was convicted and sentenced.
} Id. 22.

${ }^{38}$ Sec note 6 supra.

s" See notes 14-17 supra \& accompanying text. 
convict so that he may, if possible, become a good member of society when he is released or his term expires. ${ }^{\mathbf{6 0}}$

The California supreme court, in an oft-quoted passage, wrote: "These laws place emphasis upon the reformation of the offender.... Instead of trying to break the will of the offender and make him submissive, the purpose is to strengthen his will to do right and lessen his temptation to do wrong." 61

Some early challenges to the indeterminate sentence system focused on the issue of separation of powers. The leading case, In re Lee, answered the charge that administrative sentencing violated that constitutional principle:

[T] he legislative function is filled by providing the sentence which is to be imposed by the judicial branch upon the determination of the guilt of the offender. This is done by the enactment of the indeterminate sentence law. The judicial branch of the government is intrusted with the function of determining the guilt of the individual and of imposing the sentence provided by law for the offense of which the individual has been found guilty. The actual carrying out of the sentence and the application of various provisions for ameliorating the same are administrative in character and properly exercised by an administrative body. ${ }^{62}$

To the challenge that an indeterminate sentence is uncertain and hence cruel and unusual punishment, the courts responded that such a sentence is construed to extend for the maximum term, subject to discretionary reduction. ${ }^{63}$ When viewed in this manner, the sentence is not constitutionally frail for lack of certainty. As recently as 1968, another court reflected a similar view:

[W]e fail to see how the indeterminate sentence law, which affords a person convicted of crime the opportunity to minimize the term of imprisonment by re-

\footnotetext{
${ }^{60}$ State v. Peters, 43 Ohio 629, 646, 4 N.E. 81,85 (1885).

${ }^{61}$ In re Lee, 177 Cal. 690, 692-93, 171 P. 958, 959 (1918). See also 7 Calif. L. Rev. 132 (1919).

62177 Cal. at 693,171 P. at 959 (emphasis added).

${ }^{63}$ Id . at 695-96, 171 P. at 959; People v. Dyer, 269 Cal. App. 2d 209, 214, 74 Cal. Rptr. 764, 767 (1969); People v. Leiva; 134 Cal. App. 2d 100, 103, 285 P.2d 46, 49 (1955); State ex rel. Nelson v. Tahash, 265 Minn. 330, 121 N.W.2d 584 (1963).
} 
habilitating himself in such a manner that he may again become a useful member of society, can be held to constitute the infliction of cruel and unusual punishment. . . . To strike the law on the ground that it violates the constitutional rights of the defendant on the reasons urged would constitute a step backwards in the treatment and rehabilitation of those convicted of crime. ${ }^{64}$

The approach adopted by most courts, that the indeterminate sentence must be construed as a sentence for the maximum subject to reduction, produced a number of constitutional challenges based on the principle of "proportionality." Until recently, these challenges were uniformly rejected on the ground that legislatures have substantial discretion to impose long terms of imprisonment for criminal conduct. ${ }^{65}$ A reading of these cases suggests however, that while the courts theoretically approved long sentences for relatively minor crimes, they contemplated that the vast majority of prisoners would serve sentences significantly shorter than the maximum-an assumption which is, of course, true. Accordingly, a great deal of "proportionality" law was made in a theoretical context where the issue of long sentences for minor crimes was not presented concretely and realistically. ${ }^{66}$

During this early period, two challenges to state indeterminate sentence laws reached the United States Supreme Court. The first, Dreyer $v$. Illinois, ${ }^{67}$ raised the narrow question whether the United States Constitution was violated by a state's decision to allocate the sentencing authority, which traditionally was deemed a judicial power, to the parole board, an executive agency. A unanimous Court, in an opinion written by Justice Harlan, held that no federal constitutional question was presented by the Illinois arrangement.

${ }^{64}$ People v. Wade, 266 Cal. App. 2d 918, 928-29, 72 Cal. Rptr. 538, 544-45 (1968), cert. denied, 395 U.S. 913 (1969).

${ }^{65}$ See, e.g., United States ex rel. Palmer v. Ragen, 159 F.2d 356, 359 (7th Cir.), cert. denied, 331 U.S. 823 (1947); People v. Ralph, 24 Cal. 2d 575, 578, 150 P.2d 401, 402-03 (1944); In re Williams, 76 Cal. App. 2d 161, 165, 172 P.2d 558, 560 (1946).

${ }^{66}$ Most courts considering the constitutionality of a fixed sentence of life imprisonment for the crime of exhibitionism would react differently than if they were considering the constitutionality of an indeterminate sentence of up to life for the same crime, despite the theoretical similarity of the challenges.

${ }^{67} 187$ U.S. 71 (1902). 
The second case, Ughbanks v. Armstrong, ${ }^{68}$ presented a more general challenge to the indeterminate sentence laws of the states. Petitioner had been convicted of burglary, a crime that carried a maximum sentence of five years under the Michigan statute. The judge sentenced him "to be confined in the state prison at Jackson at hard labor for a period not less than one year and not more than two years." 69 At the end of the two years petitioner sought his release, claiming that he had completed the sentence imposed by the judge. He was turned down on the ground that the state's indeterminate sentence law provided that the maximum sentence imposed must always be the statutory maximum authorized for the particular offense; and since the statutory maximum for burglary was five years, the judicially imposed maximum of two years was superseded and void. ${ }^{70}$ Nor was petitioner eligible for discretionary release, since the state alleged that he was a twice convicted felon and, under the provisions of the indeterminate sentence laws, three-time losers had to serve the full sentence. The court rejected petitioner's claim that the state violated the sixth, eighth, and fourteenth amendments, relying primarily on the then current interpretation under which the "Sixth and Eighth Amendments do not limit the powers of the States," 71 but also considering the merits of the issue in passing. It concluded that the "act in question provides for the granting of a favor to persons convicted of crime who are confined in state prison,"72 and that the state "may (unless under extraordinary circumstances) attach such conditions to the application for, or the granting of, the favor as it may deem proper, or it may in its discretion exclude such classes of persons from participation in the favor as may to it seem fit."73 Accordingly, the state was not "bound to give the convict a hearing upon the question of prior conviction," 74 and the statute was constitutional.

The language of "favor granting" was to recur during the ensuing decades in numerous cases dealing with legislation of this type. ${ }^{75}$ Whether or not indeterminate sentence laws such

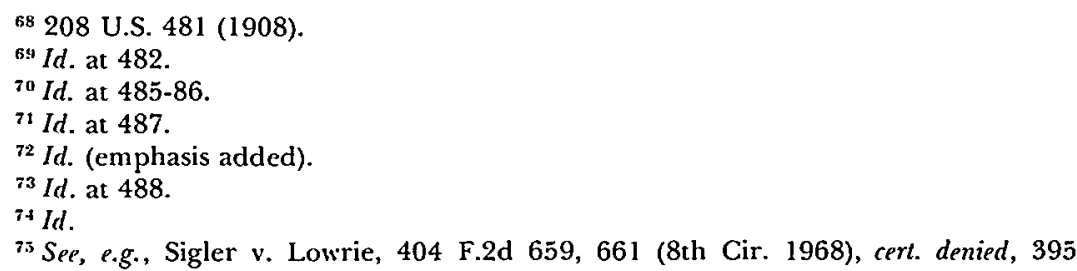


as the Michigan statute granted "favors" to other convicted criminals, it is difficult to see how Mr. Ughbanks was benefited. The judge in his case actually imposed a maximum that was three years shorter than what the indeterminate sentence law mandated. It is not surprising, therefore, that Ughbanks failed to show gratitude for the "favor" granted him by the new law. ${ }^{76}$

Until the middle of the 1960's, the courts were relatively insensitive to the constitutional implications of indeterminate confinement. ${ }^{77}$ Attention was focused on the other aspects of the criminal process, especially pretrial and trial safeguards. Little concern was expressed about deprivations of liberty that were done in the name of treatment, therapy, prevention, and rehabilitation. The two sides of this coin were reflected by the decision of the Supreme Court in Robinson $v$. California ${ }^{78}$ which held that criminal punishment could not constitutionally be imposed on a person for being addicted to the use of narcotics; he could be punished only for committing a criminal "act" within the state. The Court, however, recognized that a state could constitutionally "establish a program of compulsory treatment" requiring "periods of involuntary confinement" for addicts who had committed no criminal act within the state; so long as the confinement was "to provide or require medical treatment" and was not a "penal" or "criminal" sanction, it would not constitute "cruel or unusual punishment," even if the duration of the non-penal confinement exceeded the duration of the penal confinement struck down as unconstitutional. ${ }^{79}$ (In fact, the California "civil" confinement implicitly upheld in Robinson had longer maximum and minimum terms than the "penal" confinement declared unconstitutional.)

\section{The Emerging Attack on Indeterminate SENTENCING}

By the middle of the 1960's, a new skepticism was developing toward the rehabilitation-therapy model of confinement, of

U.S. 940 (1969); Ex parte Redwine, 91 Tex. Crim. 83, 89, 236 S.W. 96, 98 (I 921 ), aff'd per curiam, 261 U.S. 608 (1923).

${ }^{76}$ Justice Harlan, who had written the Court's opinion in Dreyer, cast the sole dissent in Ughbanks, but wrote no explanation.

7 See, e.g., Lynch v. Overholser, 288 F.2d 388 (D.C. Cir. 1961), rev'd, 369 U.S. 705 (1962).

78370 U.S. 660 (1962).

79 Id. at 665 . 
which indeterminate sentencing was a part. ${ }^{80}$ The indeterminate sentence had always been justified by analogy to other forms of indeterminate confinement, such as commitment of the mentally ill. Cesare Lombroso directly analogized indeterminate imprisonment of the "born criminal" to confinement of the insane. ${ }^{81}$ More recently another supporter of indeterminate confinement, in analogizing such confinement to the commitment of the insane, stated the commonly accepted view: "[n]o one questions the power of the state to commit to institutions mentally unbalanced persons who become dangerous to the peace and safety of the community." 82 But by the middle sixties, scholars and civil libertarians were beginning to question the government's power to confine allegedly dangerous persons for preventive and therapeutic reasons. It was only natural, therefore, that skepticism would be voiced about indeterminate sentencing. Much of this skepticism was generated by the complaints of those serving indeterminate sentences. ${ }^{83}$ These complaints began to be reflected in the literature, and stimulated criticisms of indeterminate sentencing by academics and law reformers. ${ }^{84}$ The growing skepticism among courts, legislators, and scholars during the last decade is in part a product of recent studies demonstrating that dangerousness is difficult to predict ${ }^{85}$ and that the effectiveness of treatment

${ }^{80}$ Compare Leach v. United States, 334 F.2d 945 (D.C. Cir. 1964), with Lake v. Cameron, 364 F.2d 657 (D.C. Cir. 1966).

${ }^{81}$ See text accompanying notes 40-41 supra.

${ }^{82} \mathrm{Mihm}, A$ Re-examination of the Validity of our Sex Psychopath Statutes in the Light of Recent Appeal Cases and Experience, 44 J. CRIM. L.C. \& P.S. 716, 718 (1954).

83 "There is considerable evidence, mainly in the form of testimony from prisoners and ex-prisoners of various California prisons, that indefinite sentences are one of the most painful aspects of prison life." STRUGGLe for Justice, supra note 8 , at 93. See also J. MiTFORD, supra note 9, at 87.

The prisoners' refusal to appreciate the "beneficence" of the rehabilitative purpose purportedly underlying indeterminate sentencing has often led to a charade in which the prisonwise criminal seeks to avoid an indeterminate sentence by demonstrating that he is incorrigible and not amenable to rehabilitation. For a striking example of this phenomenon, see People v. Jemmot, 50 Misc. 2d 640, 271 N.Y.S.2d 41, rev'd, 26 App. Div. 2d 937, 274 N.Y.S.2d 466 (1966).

${ }^{84}$ The 1960 's saw the general development of a "prisoners rights" movement, partly as the result of various other movements (such as "civil rights" and "war resistance") which resulted in the imprisonment of more middle class persons closer to the sources of power, influence, and publicity than the "core" population of prisons.

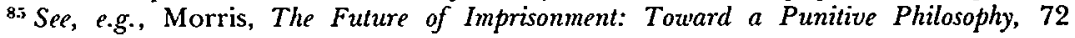
MrCH. L. Rev. 1161, I164-73 (1974) ("Despite the weight of authority supporting the principle of dangerousness, it must be rejected because it presupposes a capacity to predict quite beyond our present or foreseeable technical ability." Id. 1167.). See generally 
in reducing recidivism is open to serious question. ${ }^{86}$

From 1971 to 1973 at least three influential books were published criticizing the indeterminate sentence. The first, a report prepared for the American Friends Service Committee under the guidance of Professor Caleb Foote of Berkeley, recommended the abolition of indeterminate sentencing and the adoption of a system which proportions the punishment to the act committed (though it advocated the retention of "good time" reductions of sentence with proper safeguards). ${ }^{87}$ The Friends' report focused squarely on the preventive aspects of indeterminate sentencing: " $[T]$ he concept of preventive detention has for a century been the raison d'être for a system of indeterminate sentencing." 88 Indeed, it went beyond the indeterminate sentence and opined that in the United States today most persons who are sentenced to imprisonment are so sentenced primarily for preventive reasons:

Any prisoner denied leniency by a judge or parole board is likely to be imprisoned under a policy of preventive detention. Many, of course, are detained for retributive or general deterrence purposes. But for what is probably the majority, confinement is the result of a decision that the prisoner is not yet safe enough to release. ${ }^{89}$

The report concludes that no form of preventive detention should be tolerated, characterizing it as "a major setback in the struggle for justice" which unavoidably entails a willingness "to imprison many persons who would not have committed a crime if released, along with the few who would have."90

Diamond, The Psychiatric Prediction of Dangerousness, 123 U. PA. L. REv. 439 (1974); Dershowitz, Psychiatry and the Legal Process, 51 J. AM. Jud. Soc'y 370, 376-77 (1968).

${ }^{86}$ See, e.g., J. Conrad, Crime and Its Correction: An International Survey of Attitudes and Practices (1965); G. Kassembaum, D. Ward \& D. Wilner, Prison Treatment and Parole Survival: An Empirical Assessment 307-13 (1971); Allen, Criminal Justice, Legal Values and the Rehabilitative Ideal, 50 J. Crim. L.C. \& P.S. 226 (1959); Andanaes, The General Preventive Effects of Punishment, 114 U. PA. L. Rev. 949, 973-74 (1966); Robinson \& Smith, The Effectiveness of Correctional Programs, 17 CRIME \& Delinquency 67 (1971).

${ }^{87}$ STRUGGLE FOR JUSTICE, supra note 8 , at $147-48$.

${ }^{88}$ Id. 76.

${ }^{89} 1 d$.

${ }^{90} \mathrm{Id}$. 78. To the extent that this report suggests that preventive detention is a recent phenomenon, it is wrong. See Dershowitz, The Origins of Preventive Confinement in Anglo-American Law, 43 U. CiN. L. Rev. I (1974). 
Jessica Mitford's more popular work, Kind and Usual Punishment, focuses particularly on indeterminate sentencing as it is practiced in California. After describing its humane-sounding qualities, she poses and attempts to answer the following questions:

Why, then, is [the indeterminate sentence] denounced by the supposed beneficiaries-prisoners and parolees -from coast to coast, its abolition one of the focal demands of the current prison rebellion? And why is it coming under increasing attacks from those criminologists; sociologists, lawyers, legislators who have taken the trouble to look closely at the prison scene and have informed themselves at first hand about the day-to-day realities of prison life? ${ }^{91}$

Mitford finds many reasons for this strident opposition, including "much longer sentences for most prisoners than would normally be imposed by judges," 92 and "the total arbitrariness of the bureaucracy that rules every aspect of their existence"93 -notably the actual duration of their confinement.

The most scholarly and thoughtful of these recent works is Judge Marvin Frankel's Criminal Sentences-Law Without Order, which is a general critique of sentencing, especially in the federal courts. Finding that "the movement toward indeterminacy in sentencing is broad and powerful,"94 Frankel articulates a "minority position" that "indeterminate sentencing, as thus far employed and justified, has produced more cruelty and injustice than the benefits its supporters envisage." 95 Doubting that rehabilitation, an important justification of indeterminacy, is possible in most cases, Judge Frankel opts for a "presumption ... in favor of a definite sentence, known and justified on

91 J. MrTFORD, supra note 9 , at 81 .

92 Id. 83.

${ }^{93} \mathrm{Id} .87$.

94 "A prestigious and influential scholarly product, the Model Penal Code, provides for broadly indeterminate sentences. A number of state legislatures, including several influenced by the Model Penal Code, have opted for indeterminacy in recent revisions of their laws." $M$. Frankel, Criminal Sentences-Law Without ORDER 88 (1972).

95 Judge Frankel acknowledges the impact of prisoners' complaints on resisting the trend toward indeterminacy: "Until the last couple of years, the trend toward indeterminate sentencing has seemed irresistible. Just recently, from the prisons and elsewhere, some voices of dissent have been heard." Id. 
the day of sentencing (and probably much shorter than our sentences tend to run)." There should be

a burden of justifying an indeterminate sentence in any particular case- a burden to be satisfied by concrete reasons and a concrete program for the defendant involved. The justification ... . would consist of identified needs and resources for effective rehabilitation .... ${ }^{96}$

Frankel is also critical of other justifications for indeterminate sentencing, including the continued confinement of the dangerous offender. Finding a "wide and respectable, but risky and troublesome, trend to enact statutes for dangerous offenders authorizing long but indeterminate sentences," he raises questions "about the possibility of identifying with reasonable accuracy the dangerous individual." 97 Moreover, even if "we knew . . . how to detect who is dangerous," the question would still remain what level of risk a society should be willing to tolerate-and who should make this critical judgment. In the last analysis, Frankel reluctantly accepts the need for some indeterminacy "in the service of incapacitating dangerous people," but here too he would invoke a heavy presumption in favor of a fixed sentence in any given case. ${ }^{98}$

\section{Recent Judicial Limitations on Indeterminate SENTENCING}

\section{A. Procedural Limitations}

In the United States, judicial doubts about the substantive wisdom of particular law enforcement techniques often are reflected initially by the imposition of procedural barriers. Courts feel more comfortable placing procedural, rather than substantive, limitations on legislatively authorized programs. As Justice Harlan once said: While courts "must give the widest deference to legislative judgments" concerning the substantive criteria for confinement, the judiciary has "been understood to

:6 Id. 98.

97 "It is easy to err on the side of overcaution, resolving doubts in favor of confinement. But while that appears in fact to have happened on a large scale, nobody worth listening to commends it as a happy course for a civilized society." Id. 100 .

:B Id. 101 . 
possess particular competence" in assessing the "necessity and wisdom of procedural guarantees." 99 It is not surprising, therefore, that the initial judicial limitations on indeterminate sentencing have taken the form of procedural safeguards. Three decisions, each dealing with a different point in the indeterminate sentence process, illustrate this trend. ${ }^{100}$

In 1967, the Supreme Court imposed the first significant judicial limitation on indeterminate sentencing in Specht v. Patterson, ${ }^{101}$ which involved a Colorado sex offender act authorizing an indeterminate term of from one day to life. ${ }^{102}$ Although convicted of indecent liberties, a crime carrying a maximum sentence of ten years imprisonment, Specht was sentenced under the sex offender act which, under Colorado law, could be invoked if the sentencing judge "is of the opinion that any ... person [convicted of specified sex offenses], if at large, constitutes a threat of bodily harm to members of the public, or is an habitual offender and mentally ill." ${ }^{03}$ The Colorado statute provided for no hearing on whether the defendant constituted "a threat," and none was given Specht. Concluding that confinement under the sex offender act "is criminal punishment even though it is designed not so much as retribution as it is to keep individual from inflicting future harm,"104 the Court held that due process requires an adversary hearing, with appropriate safeguards, before a defendant can be sentenced under the sex offender statute. The Court's ruling did not extend, however, to all indeterminate sentencing. It went out of its way to distinguish the Colorado statute from the general run of indeterminate sentencing provisions. The Court noted that unlike the usual sentencing proceeding where sentence is imposed "at the end of the trial and in the same proceeding,"105 sentencing under the sex offender provision was a separate proceeding under another act, requiring "a new finding of

${ }^{99}$ In re Gault, 387 U.S. 1, 70 (1967) (Harlan, J., concurring and dissenting).

${ }^{100}$ See also the opinions of Chief Judge Bazelon in Bolton v. Harris, 395 F.2d 642 (D.C. Cir. 1968) (persons found not guilty by reason of insanity entitled to judicial hearing prior to civil commitment) and Millard v. Cameron, 373 F.2d 468 (D.C. Cir. 1966) (procedural safeguards prior to civil commitment under sexual psychopath statute).

101386 U.S. 605 (1967).

${ }^{102} I d$. at 607.

${ }^{103} \mathrm{Id}$.

${ }^{104}$ Id. at 608-09.

${ }^{105} I d$. at 606. 
fact" and "the making of a new charge leading to criminal punishment."106 The Court's opinion does not explain the theoretical or practical significance of this distinction. Surely Specht would have been no better off if the indeterminate sentence provision had been part of the original criminal prosecution, as California and other state laws now provide. But unless the Court extends the reasoning of Specht to indeterminate sentences in general, the effect of the case will be quite limited.

Specht dealt with the point at which the indeterminate sentence is judicially imposed. The next important case, Monks $v$. New Jersey State Parole Board, ${ }^{107}$ involved the point at which the actual duration of confinement is determined-the decision of the parole board to release or retain. Monks, who was serving an indeterminate sentence for a murder he committed while a juvenile, ${ }^{108}$ was denied parole on a number of occasions without any statement of the reasons. He then wrote the parole board asking "what was necessary to convince the board that he was 'a good parole risk" " so that he could "be in a position to behave in any way the Board expected."109 The board replied that "as a matter of policy" it did not give reasons for its decisions. ${ }^{110}$ The New Jersey Supreme Court held the no-reason policy invalid and ordered the parole board to substitute "a carefully prepared rule designed generally towards affording statements of reasons on parole denials, while providing for such reasonable exceptions as may be essential to rehabilitations and the sound administration of the parole system."111 Whether this rule will have any real impact on parole decisions, appellate review, or prisoners' attitudes remains to be seen.

At issue in the third illustrative decision were the demands of due process at the point after conditional release when the authorities seek to reincarcerate the parolee for alleged parole violations. As previously stated, the original proponents of the indeterminate sentence insisted that the parolee be returned to

106 Id. at $608-10$.

10758 N.J. 238, 277 A.2d 193 (1971).

108 "His period of confinement was indeterminate, to continue until the appropriate authority decided that he should be paroled though not beyond the maximum provided by law with respect to an adult." Id. at $239,277 \mathrm{~A} .2 \mathrm{~d}$ at 193.

${ }^{109} I d$. at 240,277 A.2d at 194.

110 Id. at $241,277 \mathrm{~A} .2 \mathrm{~d}$ at 194.

11 Id. at 249-50, $277 \mathrm{~A} .2 \mathrm{~d}$ at 199. 
prison "on the least well founded complaint."112 Even though parole boards might hesitate to release prisoners on parole if added procedural safeguards make quick revocation difficult, in 1972 the Supreme Court held in Morrissey v. Brewer ${ }^{113}$ that certain "basic requirements"114 of due process must apply in revocation proceedings. ${ }^{115}$ Noting that "studies have suggested that fair treatment of parole revocation will not result in fewer grants of parole," 116 the Court set out the "minimum requirements" that each state must accord the parolee:

They include (a) written notice of the claimed violations of parole; (b) disclosure to the parolee of evidence against him; (c) opportunity to be heard in person and to present witnesses and documentary evidence; (d) the right to confront and cross-examine adverse witnesses (unless the hearing officer specifically finds good cause for not allowing confrontation); (e) a "neutral and detached" hearing body such as a traditional parole board, members of which need not be judicial officers or lawyers; and (f) a written statement by the factfinders as to the evidence relied on and reasons for revoking parole. ${ }^{117}$

Once again, it remains to be seen what effect this decision may have on the various stages of the indeterminate sentencing process.

\section{B. Equal Protection}

Another indirect approach to limiting the impact of indeterminate sentencing laws has been to subject them to equal protection scrutiny. Some states have passed sentencing laws discriminatorily applying indeterminate sentences to females ${ }^{\mathbf{1 1 8}}$ - a class of offenders which early theorists thought particularly

112 Lindsey, supra note 6 , at 15 .

113408 U.S. 471 (1972).

114 Id. at 490 .

${ }^{115}$ See also Hyser v. Reed, 318 F.2d 225, 248 (D.C. Cir.) (Bazelon, C.J., concurring and dissenting), cert. denied, 375 U.S. 957 (1963).

116408 U.S. at 483.

${ }^{117}$ Id. at 489 . The Court suggested that fewer safeguards are required "in making a prediction as to the ability of the individual to live in society without committing antisocial acts" than in deciding a "wholly retrospective factual question." Id. at 480 , 479. For a critical analysis of this approach, see Dershowitz, Preventive Confinement: $A$ Suggested Frametwork for Constitutional Analysis, 51 TExAs L. REv. 1277 (1974).

118 Note 17 supra. 
amenable to rehabilitation. ${ }^{119}$ Several of these statutes recently have been held to violate the equal protection clause.

In Connecticut, the statute which was struck down permitted women to be sentenced to indeterminate terms with longer maximums than those otherwise provided for particular offenses. The leading case held that this discrimination against women did not serve a "complex of objectives" including deterrence, prevention, and rehabilitation. ${ }^{120}$ The Pennsylvania Supreme Court struck down an indeterminate sentencing law which imposed on females the same maximums as provided by statute for males, but which did not allow the judge discretion to reduce the sentence by handing down a shorter minimummaximum term. ${ }^{121}$ After noting that "the maximum sentence is the real sentence," the court found that the authorization of discretion to reduce the sentences of men only was "an arbitrary and invidious discrimination . . . with resultant injury to women."122 In 1973 the New Jersey Supreme Court held that a similar law violated the equal protection clause. ${ }^{123}$ Although the state had introduced statistics in support of the disparate sentencing scheme, the court found that " $t]$ he rationale for the classification and the different sentencing procedure-that females are better subjects for rehabilitation, thereby justifying a potentially longer period of detention for that purpose-finds little or no support, empirical or otherwise, in the record."124

These cases testing disparate sentencing schemes called upon the courts to evaluate rehabilitation as a justification for the disparities. Earlier courts had upheld similar or identical schemes involving discriminatory indeterminate sentences for

${ }^{119}$ Commonwealth v. Daniels, 210 Pa. Super. 156, 171 n.2, 232 A.2d 247, 255 n.2 (1967) (Hoffman, J., dissenting), rev'd sub nom. Commonwealth v. Daniel, 430 Pa. 642, 243 A.2d 400 (1968); see Comment, supra note 17.

120 United States ex rel. Robinson v. York, 281 F. Supp. 8, 15-16 (D. Conn. 1968). See also cases cited in note 17 supra.

121 Commonwealth v. Daniel, 430 Pa. 642, 243 A.2d 400 (1972).

122 Id. at $647-48,243 \mathrm{~A} .2 \mathrm{~d}$ at 403 . The court also noted the appellants' contentions that the system worked injustice with respect to parole, in two ways. First, the minimum sentence given to men in fact spurred release on parole, for review was required upon completion of the minimum term; women were technically eligible for parole at any time, but no review by the parole board was required. Secondly, men, once paroled, were subject to reincarceration for parole violations only during the judgeimposed maximum sentence, rather than during the maximum provided by the statute, which applied to the women. Id. at 647 \& n.6, 243 A.2d at 402 \& n.6.

${ }^{123}$ State v. Chambers, 63 N.J. 287, 307 A.2d 78 (1973).

124 Id. at 296,307 A.2d at 82. 
women on the ground that the rehabilitation goal was a forward step in penal reform, beneficial to the inmates. ${ }^{125}$ The recent decisions reflect more skeptical judgments. This has been characterized as "increasing disillusionment about the practical administration of the rehabilitative ideal," ${ }^{26}$ but it may extend to disillusionment with the ideal itself.

\section{Substantive Limitations}

The "procedural" and sex discrimination cases, while reflecting a growing concern about the abuses of indeterminate sentencing, do not impose any direct constraints on such sentences. In re $L y n c h,{ }^{127}$ a recent decision by the California Supreme Court, may mark the beginning of significant substantive constraints on the extent of indeterminacy in sentencing.

The factual setting in Lynch was extremely sympathetic. In 1967 , Lynch, a person of "superior intellect," apparently was seen masturbating in his own car at 2:45 a.m. in the lot of a drive-in restaurant. This offense, standing alone, would have been a misdemeanor punishable by six months imprisonment under California law. But because Lynch had a 1958 conviction for indecent exposure (for which he had been placed on probation), he was given an indeterminate sentence. At the time of his appeal, he had already served more than five years in prison-"three and a half of those years in the maximum security confines of Folsom."128

In a thoughtful and detailed opinion, the court held that an indeterminate sentence of up to life for a second indecent exposure conviction violated the "cruel or unusual punishment" prohibition of the California constitution, because the maximum possible punishment was disproportionate to the underlying offense. The court was careful, however, not to strike down the indeterminate sentence law on its face. ${ }^{129}$ "The fault does

${ }^{125}$ See cases cited in notes 60-64 supra, and in Note, Longer Sentences for Females Than for Males Convicted of the Same Offense Denies Equal Protection, 82 Harv. L. Rev. 921, 924-25 (1969).

${ }^{126}$ Id. 925.

1278 Cal. 3d 410, 503 P.2d 921, 105 Cal. Rptr. 217 (1972).

${ }^{128} \mathrm{Id}$. at 438,503 P.2d at 940,105 Cal. Rptr. at 236 . Lynch also challenged his confinement on the familiar ground that the repeated denial of his parole was based on his refusal to confess to having committed additional acts of indecent exposure. Id. at $438 \mathrm{n} .26,503$ P.2d at 940 n.26, 105 Cal. Rptr. at 236 n.26. The court did not reach that issue.

${ }^{12 "} I d$. at 415, 503 P.2d at 923, 105 Cal. Rptr. at 219. 
not lie in the theory of the indeterminate sentence law," it said, "but in the unreasonably high maximum term prescribed for this offense." ${ }^{130}$ Nevertheless, the opinion does have significant implications for indeterminate sentencing. In assessing the proportionality of an indeterminate sentence to its underlying offense, the court regarded the maximum possible sentence as the sentence imposed. Thus even if the prisoner is very unlikely to serve the maximum (even if the median sentence served for a given offense is a fraction of the maximum), the court will ask whether the maximum is disproportionate to the underlying offense. This aspect of the ruling is applicable generally to all indeterminate sentencing, and promises to bring into sharper focus the whole issue of proportionality in the context of indeterminate sentencing.

Having decided that Lynch must be deemed to be serving a life sentence for a second indecent exposure conviction, the court then asked whether a punishment can be regarded as "cruel or unusual" if it is disproportionate to the underlying crime. The conventional wisdom has long been that the "cruel and unusual punishment" prohibition of the Federal Constitution, which is analogous to the California provision, is directed primarily, if not exclusively, at the method of the punishment employed, and not at its duration; it was "traditionally thought to prohibit physically torturous methods of punishment such as the rack and the screw."131 But the California Supreme Court marshalled all the case law, state and federal, in support of the proposition that a conventional method of punishment, such as imprisonment, could be cruel or unusual if its duration were excessive in relation to the offense charged. ${ }^{132}$ After reviewing several tests of proportionality, the court concluded:

[I]n California a punishment may violate article I, section 6, of the Constitution if, although not cruel or unusual in its method, it is so disproportionate to the

$130 \mathrm{Id}$. at 438,503 P.2d at 940, 105 Cal. Rptr. at 236.

${ }^{131}$ Id. at 421,503 P.2d at 928,105 Cal. Rptr. at 224.

132 The court cited a series of ambiguous Supreme Court decisions including Furman v. Georgia, 408 U.S. 238 (1972), and a number of decisions directly on point from several states (some of which have constitutional provisions expressly requiring that criminal penalties must be proportioned to the offense). $8 \mathrm{Cal}$. 3d at 422-23, 503 P.2d at 928-29, 105 Cal. Rptr. at 224-25. See also Watson v. United States, 439 F.2d 442, 464 (D.C. Cir. 1970) (appended opinion of Chief Judge Bazelon, subsequently vacated en banc). 
crime for which it is inflicted that it shocks the conscience and offends fundamental notions of human dignity. ${ }^{133}$

The court catalogued several factors to be considered in administering this open-ended rule.

First, judges should examine "the nature of the offense and/or the offender, with particular regard to the degree of danger both present to society." 134 Was the crime violent or nonviolent; were there aggravating circumstances; was anyone injured?

These guidelines, while useful at the extremes, are of little help in resolving the really difficult cases involving inchoate, preparatory, or regulatory crimes, such as failure to inspect food products, carrying of unlicensed firearms, or driving in a dangerous fashion. Each of these crimes carries a considerable risk of death or serious injury; yet they are not thought to reflect the culpability warranting extremely high penalties. This formulation also ignores the extraordinarily difficult question whether a rule of proportionality can-justly or constitutionally -take into account the fortuitous results of a criminal's actions, whether such fortuities result in greater or lesser harm than was intended. ${ }^{135}$ But it is perhaps too much to ask of an initial judicial foray into proportionality that it resolve complex issues which have troubled mankind from the beginning of time.

The second factor focused on by the California court was a comparison of "the challenged penalty with the punishments prescribed in the same jurisdiction for different offenses which, by the same test, must be deemed more serious."136 In order to employ this approach, a court would have to erect (implicitly or explicitly) a rough rank order of seriousness, place the crime in question in that order, and then determine whether other crimes which are higher on the scale of seriousness are punished less severely. For example, it would be improper to punish indecent exposure more severely than crimes such as robbery, rape, or violent assault.

1338 Cal. 3d at 424, 503 P.2d at 930, 105 Cal. Rptr. at 226.

${ }^{134} \mathrm{Id}$. at 425,503 P.2d at 930,105 Cal. Rptr. at 226.

${ }^{135}$ See generally Schulhofer, Harm and Punishment: A Critique of Emphasis on the Results of Conduct in the Criminal Law, 122 U. PA. L. Rev. 1497 (1974).

1368 Cal. 3d at 426, 503 P.2d at 931, 105 Cal. Rptr. at 227. 
There are a number of difficulties with any such comparison. One such difficulty results when the legislature imposes more severe punishment for repeated instances of a less serious offense than it does for a single instance of a more serious offense. How much weight must be given, in computing the constitutional calculus, to the seriousness of the offense as compared to its frequency? The Lynch court addressed that problem, at least at its extremes. It held that frequency of the offense and even likely recidivism do "not result in a pro tanto repeal of the cruel or unusual punishment clause."137 The court compared the seriousness of second offender exhibitionists to first offender burglars, arsonists, and drunken drivers and concluded that the latter groups must be deemed more serious offenders than the former. Moreover, the court also found that, in contrast to second offender exhibitionists, many offenders convicted of two violent crimes are subject to less than life imprisonment under California law.

But the court did not directly confront the most difficult problem inherent in the ranking approach: how is the ranking to be done and by whom? Again this is easy at the extremes: all reasonable people must conclude that exhibitionism is less serious than rape and more serious than private possession of pornography. But how does one go about deciding whether unaggravated rape is more or less serious than aggravated physical assault, whether surreptitious burglary is more serious than purse-snatching, or whether drunken driving is more serious than sale of marijuana or pornography? Alternative ways of making this ranking suggest themselves. First, the courts could look at how popular opinion regards the comparative seriousness of crimes; but according to our political theory popular opinion is supposed to be reflected in legislative enactments, and the issue is whether the courts should find these enactments unconstitutional. Secondly, the courts could look to some inherent moral considerations in ranking seriousness; this is in effect simply adding an ingredient to the first approach articulated in Lynch. Thirdly, the courts may look at how other jurisdictions rank the seriousness of offenses. This is what the court described as the third technique to be used in administering the proportionality rule.

${ }^{137}$ Id. at 432, 503 P.2d at 936, 105 Cal. Rptr. at 232. 
The third approach compares "the challenged penalty with the punishments prescribed for the same offense in other jurisdictions having an identical or similar constitutional provision." 138 This sort of cross-jurisdictional comparison is traditional in constitutional adjudication and is suggested by the text of the constitutional provision itself which prohibits "unusual" punishments.

But it is more difficult to apply than the Lynch opinion suggests. After reviewing "the indecent exposure statutes of each of our sister states," the court concluded that only two permit life maximum sentences for second-offense exhibitionists, and most punish it relatively lightly. ${ }^{139}$ This survey neglects to consider provisions other than indecent exposure statutes themselves that may mandate long-term confinement for second offender exhibitionists. ${ }^{140}$ For example, a considerable number of states have sexual psychopath laws (or other special provisions for sex offenders) which authorize lifetime confinement for persons with a history of sex offenses; these statutes have generally been construed to apply to exhibitionists. Thus, the Lynch court was incorrect in its assertion that "it is the virtually unanimous judgment of our sister states that indecent exposure, no matter how often it may recur, can be adequately and appropriately controlled by the imposition of a short jail sentence and/or a small fine."141 This is simply not the case: a considerable number of states have concluded that exhibitionists cannot be adequately dealt with by a short jail sentence or fine, that they must be confined indefinitely as sexual psychopaths, perhaps for the rest of their lives.

Indeed, California itself has a sexual psychopath law that authorizes indefinite confinement, even for life, of sex offenders, apparently including exhibitionists. In People v. Levy, ${ }^{142}$ the California district court of appeal had upheld that statute and justified confinement even in the absence of treatment on the

${ }^{138} I d$. at 427,503 P.2d at 932,105 Cal. Rptr. at 228.

${ }^{139}$ Id. at 436,503 P.2d at 938,105 Cal. Rptr. at 234.

${ }^{140}$ This approach, in general, requires undue formalism. Different jurisdictions often label similar acts differently. For the approach to be meaningful, a more complex functional analysis of how various acts are actually punished, without regard to formal labels, would be required.

1418 Cal. 3d at 436, 503 P.2d at 939, 105 Cal. Rptr. at 235.

142151 Cal. App. 2d 460, 311 P.2d 897 (1957). 
reasoning that "[t]he main purpose of the Act is to protect society against the activities of sexual psychopaths. The secondary purpose is to rehabilitate the sexual psychopath."143

It is unclear from the California Supreme Court's opinion in Lynch whether a potentially life-long prison confinement of an exhibitionist under the sexual psychopath law-rather than under the indeterminate sentencing law-would now survive constitutional attack. If so, the prosecution could easily circumvent the Lynch holding, at least in the area of crimes having a sexual component. But there is no rational way to distinguish between a potential life "sentence" imposed under an indeterminate sentencing law and life "commitment" imposed under a sexual psychopath law. The Levy court's attempt to differentiate sexual psychopath commitment and ordinary criminal confinement is less than compelling:

The emphasis that appellant places on the fact that he was originally convicted of a misdemeanor, and now finds himself in San Quentin, possibly for life, is misplaced. The argument would be sound only were his confinement punishment. ... [But] the purpose of the confinement is to protect society and to try and cure the accused. ${ }^{144}$

The purpose of indeterminate sentencing likewise is to protect society and rehabilitate the accused. ${ }^{145}$ As the Lynch court said:

${ }^{143} \mathrm{Id}$. at 468, $311 \mathrm{P} .2 \mathrm{~d}$ at 902. Contrast Chief Judge Bazelon's opinion in Rouse $\mathrm{r}$. Cameron, 373 F.2d 451 (D.C. Cir. 1966) (person acquitted by reason of insanity has right to treatment after involuntary commitment).

144151 Cal. App. 2d at 468, 311 P.2d at 902.

145 First, the theory of the indeterminate sentence law in California is that it permits the shortening of a defendant's sentence upon a showing of rehabilitation. This has not always been the reason invoked elsewhere for indeterminate sentence laws. When they first came into use-in certain countries of continental Europe in the 18th and 19th centuries-their purpose was to the contrary, i.e., to permit the lengthening of sentences for the preventive detention of dangerous unrehabilitated criminals who had served their original terms. By the middle of the 19th century, however, such laws had generally disappeared. And when the indeterminate sentence system was revived by American prison reformers in the latter part of the century, its purpose was wholly ameliorative. The goal of its proponents was to individualize the rehabilitation process, and to use the povier to shorten sentences as an incentive to reformation.

8 Cal. 3d at 416, 503 P.2d at 924, 105 Cal. Rptr. at 220 (citing Sellin, Indeterminate Sentence, 4 ENCYC. Soc. Sci. 650-51 (1937)). See also id. at 415 n.3, 503 P.2d at 924 n.3. 105 Cal. Rptr. at 220 n.3. 
Indeterminate sentence laws "place emphasis upon the reformation of the offender." 146 To describe an indeterminate sentence as "punishment" while characterizing identical confinement under the sexual psychopath law as something other than punishment is to employ a " "civil' label of convenience," which has been discredited by the United States Supreme Court. ${ }^{147}$ Indeed, the Court has expressly held that a sanction is not eliminated from the category of punishment just because its purpose is preventive. In United States $v$. Brown, ${ }^{148}$ the government argued that the disqualification at issue was "preventive rather than retributive in purpose." 149 The Court responded as follows:

It would be archaic to limit the definition of "punishment" to "retribution." Punishment serves several purposes; retributive, rehabilitative, deterrent-and preventive. One of the reasons society imprisons those convicted of crimes is to keep them from inflicting future harm, but that does not make imprisonment any the less punishment. ${ }^{150}$

Accordingly, there is little basis for distinguishing sexual psychopath laws from indeterminate sentencing laws. This issue was not reached in Lynch, but was discussed by Chief Judge David Bazelon and by Chief Justice (then Circuit Judge) Warren Burger in the 1969 case of Cross $v$. Harris. ${ }^{151}$

Cross was a chronic exhibitionist who had first been committed as a sexual psychopath in 1952 when he was eighteen years old. This commitment, premised on his "tendency to indecently expose himself in public," lasted for fifteen years, although the crime of indecent exposure in the District of Columbia "is ordinarily punishable by a jail sentence of not more than 90 days." 152 Several months after his release in 1967, he was again arrested for six different acts of exhibitionism. The government moved for his indeterminate commitment as a sexual psychopath. The examining psychiatrists both agreed that he was a sexual psychopath but recommended out-

${ }^{1 * 6} \mathrm{Id}$. at $416,503 \mathrm{P} .2 \mathrm{~d}$ at $924,105 \mathrm{Cal}$. Rptr. at 220.

${ }^{147}$ See In re Gault, 387 U.S. 1, 50 (1967).

148381 U.S. 437 (1965).

${ }^{149} I d$. at $456-57$.

${ }^{150}$ Id. at 458 .

151418 F.2d 1095 (D.C. Cir. 1969).

1.52 Id. at 1096 . 
patient care rather than confinement. Notwithstanding this recommendation and the conclusion of the psychiatrists that confinement would not "benefit . . . anyone," 153 the district court ordered him committed, and later denied his petition for a writ of habeas corpus. On appeal, Chief Judge Bazelon wrote the majority opinion, remanding the case to the district court for further findings. Judge Burger filed a scathing dissent.

Judge Bazelon argued that the indeterminate confinement of an exhibitionist would raise serious constitutional questions, regardless of whether that confinement was labeled "civil" or "criminal." Such "incarceration may not seem "punishment' to the jailors, but it is punishment to the jailed."154 It would, argued Judge Bazelon, deprive Cross "of his liberty indefinitely-and perhaps permanently-for a propensity to commit acts punishable by a fixed jail sentence" of ninety days. ${ }^{155}$

Judge Burger disagreed that an indeterminate sentence would raise constitutional issues:

A civil commitment statute is not rendered constitutionally suspect as a form of preventive detention sim-

${ }^{153} \mathrm{Id}$.

154 We have not ... decided any constitutional questions. But when a determination of "dangerousness" will result in a deprivation of liberty, no court can afford to ignore the very real constitutional problems surrounding incarceration predicated only upon a supposed propensity to commit criminal acts. Incarceration may not seem "punishment" to the jailors, but it is punishment to the jailed. Incarceration for a mere propensity is punishment not for acts, but for status, and punishment for status is hardly favored in our society. In essence, detention for status is preventive detention.

Only a "blind court" could ignore the intense debate, in and out of Congress, over the extent to which the Constitution can tolerate preventive detention. Similar questions have been raised sporadically for years, but the problem has rarely been analyzed. It may be that in some circumstances preventive detention is in fact permissible. If so, such detention would have to be based on a record that clearly documented a high probability of serious harm, and circumscribed by procedural protections as comprehensive as those afforded criminal suspects. Detention for any significant period of time would have to be attended by periodic review as well as continuing assurance of bona fide efforts at treatment suited to the particular individual detained.

Id. at 1101-02.

${ }^{155}$ Id. at 1103. See also Bazelon, Implementing the Right to Treatment, 36 U. CHI. L. REv. 742, 749 (1969):

The aresome uncertainty about dangerousness . . . is tolerated [in civil commitment proceedings] on the rationalization that the person is not being imprisoned, but rather. hospitalized for treatment. Of course, when no treatment is forthcoming, we cluck sympathetically but reluctantly refuse to release the individual because he is dangerous.

This chicanery is intolerable. 
ply because in a given case the civil confinement may exceed the sentence which could be imposed under a criminal statute for the same acts. The possible disparity of confinement, which is by no means inevitable, may reasonably be justified by the social desirability and public necessity of providing the patient with therapy. ${ }^{156}$

He concluded that society must be empowered to "remove" the "lewd actor" from public areas "gently but firmly-in order to protect the public and to carry out corrective treatment." 157 If the corrective treatment requires lifetime confinement, that is a cost worth exacting in order to prevent psychic trauma to the potential victims of an act of exhibitionism.

But it was precisely this problem of disproportionality which Judge Bazelon considered to be of constitutional dimensions. He enumerated the constitutional questions which the district court would have to face if it found that Cross was a sexual psychopath within the meaning of the District of Columbia statute: ${ }^{158}$

(1) Is the harm threatened by a potential exhibitionist sufficiently serious to provide a constitutional justification for indefinite deprivation of liberty?

(2) Is the possibility that no harm will in fact result from appellant's future conduct sufficiently large to make incarceration based on possible harm arbitrary and capricious and therefore in violation of the due process clause?

(3) Does the Sexual Psychopath Act provide adequate procedural due process to permit indefinite detention?

(4) Is the absence in the Sexual Psychopath Act of the procedural protections accorded those sought to be committed under the 1964 act a denial of equal protection?

156418 F.2d at 1109 .

${ }^{157} \mathrm{Id}$. at 1110 .

158 The case was remanded for a determination whether Cross was a sexual psychopath within the meaning of the act, which Judge Bazelon interpreted to require a high probability of substantial injury. The district court was instructed to determine under the statute "whether appellant's potential exhibitionism can be deemed a sufficiently grave danger to warrant an indeterminate commitment." Id. at 1100-02. 
(5) In view of 1964 Act, does the equal protection clause require consideration of the adequacy of less restrictive alternatives to hospital confinement for a "sexual psychopath"?

(6) If less restrictive alternatives would in fact adequately protect the public while best promoting appellant's rehabilitation, is confinement a deprivation of his liberty without the justification required by the due process clause?

(7) If appellant's need for treatment requires that he not be confined, is indefinite confinement because of his condition cruel and unusual punishment? ${ }^{159}$

The importance of Judge Bazelon's questions in Cross, and of the court's holding in Lynch, is that they exemplify a judicial willingness to impose considerations of proportionality on confinement whose purpose is rehabilitative. Lynch actually imposed a constitutional requirement of proportionality in the context of a criminal indeterminate sentence law; Judge Bazelon's opinion in Cross would extend this principle to "civil" confinements and would require proportionality between the duration of such confinements and the seriousness and likelihood of predicted future acts.

The United States Supreme Court also recently has suggested that it may begin to consider the constitutionality of disproportionately long confinement, even if it purports to be nonpunitive. In Jackson $v$. Indiana, ${ }^{160}$ the Court struck down a state statute authorizing the indeterminate commitment of persons found incompetent to stand trial. It held that such a person "cannot be held more than the reasonable period of time necessary to determine whether there is a substantial probability that he will attain that capacity in the foreseeable future."161 The Court also raised, but did not answer, some broad questions about the government's power to order indeterminate commitments in general:

The States have traditionally exercised broad power to commit persons found to be mentally ill. The sub-

159 Id. at 1103 (emphasis added).

160406 U.S. 715 (1972).

161 Id, at 738 . 
stantive limitations on the exercise of this power and the procedures for invoking it vary drastically among the States. The particular fashion in which the power is exercised-for instance, through various forms of civil commitment, defective delinquency laws, sexual psychopath laws, commitment of persons acquitted by reason of insanity-reflects different combinations of distinct bases for commitment sought to be vindicated. The bases that have been articulated include dangerousness to self, dangerousness to others, and the need for care or treatment or training. Considering the number of persons affected, it is perhaps remarkable that the substantive constitutional limitations on this power have not been more frequently litigated. ${ }^{162}$

This unambiguous invitation to litigation is bound to stimulate lawsuits challenging the constitutionality of various forms of indeterminate confinement. Some of these challenges undoubtedly will focus on the lack of proportionality inherent in most indeterminate confinements. It is unlikely that these cases will mark the end of indeterminate sentencing in the United States; the concept is too deeply entrenched in our law and practices. Nevertheless the trend is clearly in the direction of limiting the reach of indeterminate sentencing, and courts have already begun to reflect the growing academic and inmate criticism of these laws. It is likely that the process of judicial retrenching will continue in the United States.

\section{EPILOGUE}

Every legal system inevitably reflects the tension between efficiency and justice. It has been Judge Bazelon's calling to nudge the process of confinement more in the direction of justice. His weapon has been the question. More than any other judge, he has, in his judicial opinions and articles, raised the most difficult and challenging questions about our system of confinement. He has understood Justice Jackson's dictum that "[q]uestioning is an indispensable instrumentality of justice." 163 His mission has been to ventilate the issues; to expose them for further debate and consideration. It is not surprising, there-

${ }^{162} I d$, at 736-37 (footnotes omitted).

${ }^{163}$ Ashcraft v. Tennessee, 322 U.S. 143, 160 (1944) (Jackson, J., dissenting). 
fore, that his opinions have consistently, over the years, generated scholarly articles and books. Scholars have not always agreed with his conclusions, but they have not been able to ignore his questions. Generations from now, courts, legislatures, scholars, and students will be grappling with the questions raised in his opinions. Judge Bazelon has not always provided the answers to these questions. But as Paul Freund has observed, the most meaningful answer may be the question. 